\title{
Correction to: Connexin 32 plays a crucial role in ROS-mediated endoplasmic reticulum stress apoptosis signaling pathway in ischemia reperfusion-induced acute kidney injury
}

Yu Gu${ }^{\dagger}$, Fei Huang ${ }^{\dagger}$, Yanling Wang ${ }^{\dagger}$, Chaojin Chen, Shan Wu, Shaoli Zhou* , Ziqing Hei ${ }^{*}$ and Dongdong Yuan ${ }^{*}$

\section{Correction to: J Transl Med (2018) 16:117}

https://doi.org/10.1186/s12967-018-1493-8

Following publication of the original article [1], the authors reported errors in Fig. 5a, e. The GAPDH band in Fig. 5a was duplicated with Fig. 4b GAPDH band. In
Fig. 5e, the sham picture $(\mathrm{Cx} 32+/+$, sham, GRP78) and the sham pictures (Cx32-/-, sham, GRP78, CHOP) were duplicated. The correct version of Fig. 5 is given below.

*Correspondence: 13610272308@139.com; heiziqing@sina.com; yuandongdong123@126.com

${ }^{\dagger}$ Yu Gu, Fei Huang and Yanling Wang contributed equally to this work Department of Anesthesiology, The Third Afliated Hospital of Sun Yatsen University, No. 600 Tianhe Road, Guangzhou 510630, Guangdong Province, China

(c) The Author(s) 2020. This article is licensed under a Creative Commons Attribution 4.0 International License, which permits use, sharing, adaptation, distribution and reproduction in any medium or format, as long as you give appropriate credit to the original author(s) and the source, provide a link to the Creative Commons licence, and indicate if changes were made. The images or other third party material in this article are included in the article's Creative Commons licence, unless indicated otherwise in a credit line to the material. If material is not included in the article's Creative Commons licence and your intended use is not permitted by statutory regulation or exceeds the permitted use, you will need to obtain permission directly from the copyright holder. To view a copy of this licence, visit http://creativeco mmons.org/licenses/by/4.0/. The Creative Commons Public Domain Dedication waiver (http://creativecommons.org/publicdomain/ zero/1.0/) applies to the data made available in this article, unless otherwise stated in a credit line to the data. 

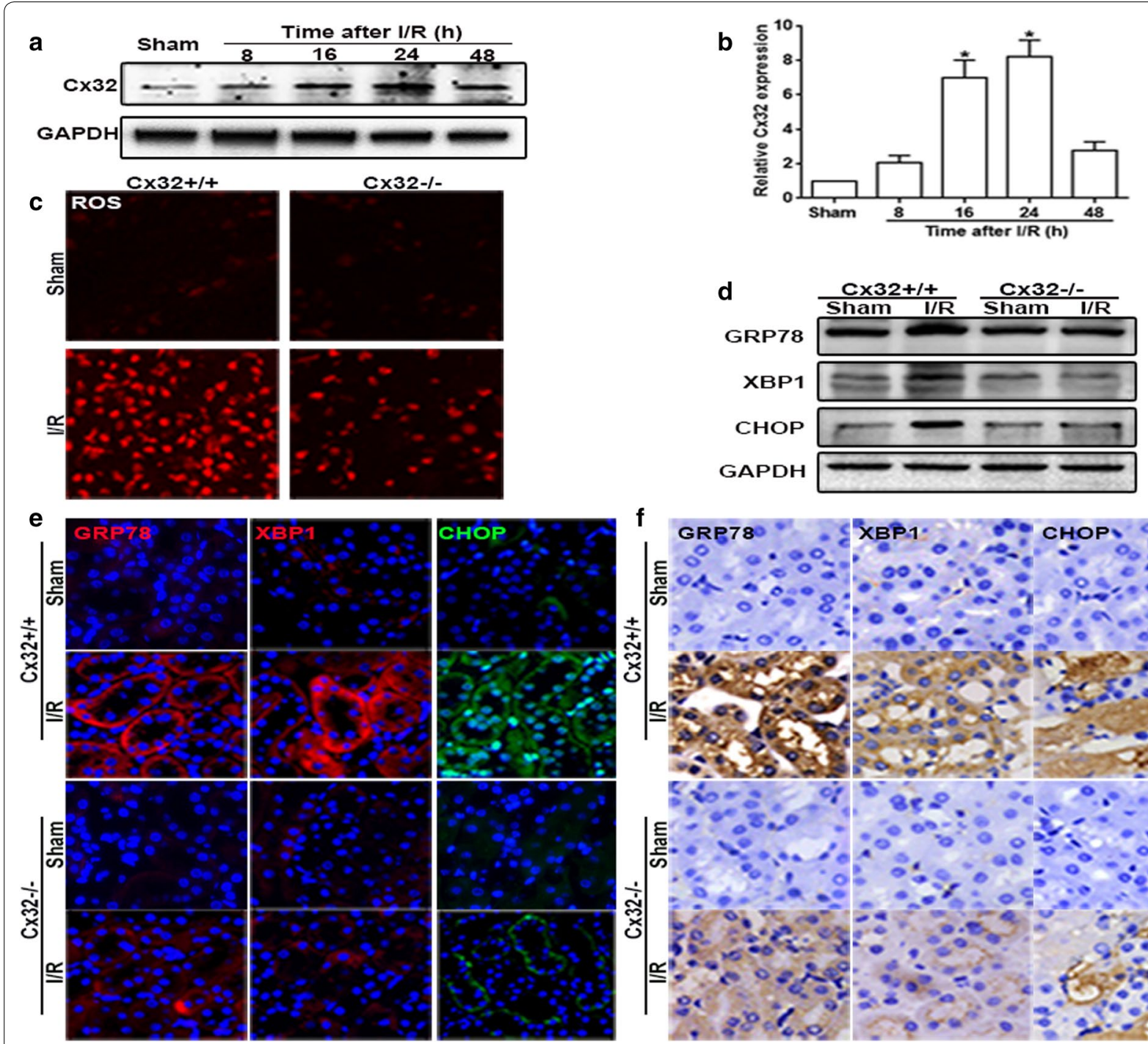

Fig. 5 Cx32 gene deletion mitigated I/R-induced ROS generation and ERS activation. $\mathbf{a}$, b Renal I/R induced the alteration of Cx32 protein expression was detected by western blotting analysis. $n=6,{ }^{*} p<0.05$ vs Sham group. $\mathbf{c} C \times 32$ gene deletion significantly alleviated ROS production and distribution (magnification $\times 200$ ). $\mathbf{d}-\mathbf{f}$ CX32 gene deletion significantly alleviated I/R (24 h)-induced GRP78, XBP1and CHOP expression increase. Changes of GRP78, XBP1 and CHOP expressions were determined by western blotting analysis. Immunofluorescence staining (magnification $\times 400$; red: GRP78 and XBP1; green, CHOP; blue: the nuclear labeled by DAPI) and immunohistochemistry (magnification $\times 400$ )

Published online: 27 May 2020

\section{Reference}

1. GuY, Huang F, Wang Y, Chen C, Wu S, Zhou S, Hei Z, Yuan D. Connexin32 plays a crucial role in ROS-mediated endoplasmic reticulum stress apoptosis signaling pathway in ischemia reperfusion-induced acute kidney injury. J Transl Med. 2018;16:117. https://doi.org/10.1186/s1296 7-018-1493-8

\section{Publisher's Note}

Springer Nature remains neutral with regard to jurisdictional claims in published maps and institutional affiliations. 